\title{
COMMUNITY PROPERTY CLAIMS IN THE PERSONHOOD PERSPECTIVE: PART 1
}

\author{
Natalie Pratt*
}

\section{INTRODUCTION}

Western understanding of property has traditionally followed the Blackstonian conception of:

...that sole and despotic dominium which one man claims and exercises over the external things of the world, in total exclusion of the right of any other individual in the universe. ${ }^{1}$

Whilst this infamous quote is often cited out of context, the right to exclude others is still recognised as the hallmark of the property rights enjoyed by a titleholder.

Communal property arrangements are in sharp decline, especially in capitalist economies. Social and economic policy favour those who use by taking resources and excluding others, as opposed to those who use a resource whilst sharing it. By using a number of models (such as the tragedy of the commons, the prisoner's dilemma or the logic of collective action), ${ }^{2}$ social scientists, economists and lawyers have all argued for the privatisation of natural resources at the expense of common-property regimes. Common-property suffers a stigmatisation; it is often considered an arrangement that is marred by the mismanagement of resources, confined to the developing world and intrinsically linked to poverty. ${ }^{3}$ Consequently, very little provision is made in English law for communal property arrangements, and there is no real legal mechanism that can

\footnotetext{
* Teaching Fellow, Dickson Poon School of Law, King's College London.

${ }^{1}$ Sir William Blackstone, Commentaries on the Laws of England (Chicago University Press 1979) 2.

${ }^{2}$ Elinor Ostrom, Governing the Commons: The Evolution of Institutions for Collective Action (Cambridge University Press 1990).

${ }^{3}$ CF Runge, 'Common Property and Collective Action in Economic Development' in DW Bromley (ed), Making the Commons Work: Theory, Practice and Reality (San Francisco: Institute for Contemporary Studies 1992) 17.
} 


\section{COMMUNITY PROPERTY CLAIMS}

adequately accommodate this alternative method of property holding. ${ }^{4}$ The trust and the corporate form can be manipulated to enable communities to control and hold title to land, but are not mechanisms that are designed or inherently suited to such a purpose. Even newer initiatives, such as community land trusts, ${ }^{5}$ are bound to the existing legal forms and have not developed new title holding mechanisms in favour of the community, thus limiting their impact in furthering the communal property cause.

Notwithstanding the prevalent trend of the privatisation of resources, our legal doctrine strongly suggests that some kinds of property should not be exclusively private; but rather should be open to the public or subject to the jus publicum. ${ }^{6}$ Indeed, it has also been argued that communal resource use is a "versatile and endemic phenomenon, not a relic of past or primitive societies". ${ }^{7}$ Empirical studies of communal resources have demonstrated that common-property arrangements can, and do, survive. Moreover, new de facto common-property arrangements are arising, and yet there is an inadequate legal framework in practice to recognise them. Modern commons scholarship is trying to reverse the marginalisation of commonproperty arrangements, the first step of which is to justify these arrangements, as this article aims to do.

This two-part article seeks to expose the imbalance between communal and private property arrangements by justifying communal property claims using a theory that is frequently invoked to justify private property: the personality theory of property. It is argued that if a community of users can establish a claim within the personhood perspective, that claim should be treated with the same respect as the private property claim founded through the same mechanism. Where competing claims to natural resources (specifically land) exist, it should not always be the private property claim of an individual landowner that takes priority when the other claimant is a community of users. If both claims can be justified through the same mechanism, both should be treated with equal weight and consideration.

Part II of this instalment examines the personality theory of property as traditionally applied to justify private property claims, and suggests that this justificatory framework could, in theory, be applied to a communal claim. Part III acknowledges that the personhood claim cannot be applied

\footnotetext{
${ }^{4}$ English law currently restricts the number of individuals who may collectively hold title to a resource to four persons, as per s 34 Law of Property Act 1925.

${ }^{5}$ Housing and Regeneration Act 2008, s 79.

${ }^{6} \mathrm{C}$ Rose, Property and Persuasion: Essays on the History, Theory and Rhetoric of Ownership (Westview Press Inc 1994) 106.

7 A Clarke, 'Creating New Commons: Recognition of Communal Land Rights within a Private Property Framework' (2006) 59 (1) Current Legal Problems 319, 325 .
} 
to simply any group to substantiate a successful property claim, and examines the requisite group characteristics that allow the application of the theory. The second instalment of this two-part article will then apply the personality theory of property to the limited number of community claims that are recognised in English law. It will be shown that the personality theory of property is not yet operative in the community context, and does not protect community entitlement in the way that it protects the entitlement of private individuals. The second instalment also explores why community entitlement to property fails to adhere to the personality theory, and points to the inconsistency between the nature of the community claim and the dominant narrative in property discourse. Finally, it will be suggested that whilst recent political initiatives purport to have given greater weight to community entitlements to property, this is in fact a ruse. The outcome of the policies aimed at recognising the community claim is little more than a perpetuation of the preference for private property initiatives.

The reluctant conclusion of these papers is that a community of users cannot establish an entitlement to the resource that they use through the personality theory of property. Whilst in theory claims of a community should be respected in the same way as claims of individuals under the personhood perspective, this is impossible as long as the dominant narrative of property is that of the self-interested individual. The English legal system does not understand the nature of communal claims, and all attempts to introduce policies and mechanisms that recognise and accommodate community claims to land have proved ineffective. Allocation of, and entitlement to, natural resources not only relies on the dominant property narrative, but also the political climate in which the narrative is developed. The political climate is such that promoting community entitlement to property is not advantageous to realising the economic aims of the government, which, in light of the recent economic downturn, can only really favour the instrumental and fungible property claim.

\title{
2. THE PERSONALITY THEORY OF PROPERTY
}

\author{
Instinctive impulse drives us to collect property; and the collections \\ thus made become, with different degrees of intimacy, parts of our \\ empirical selves. ${ }^{8}$
}

The personality theory of property, also referred to as property and personhood (the terms are used interchangeably), is traditionally used to

${ }^{8}$ W James, The Principles of Psychology (Henry Holt and Co Inc 1890) 293. 
justify private property claims. The essence of the theory is that an individual embodies himself or herself in the external world by projecting their will into external unoccupied objects. The property becomes bound up with their personality, and is a constitutive part of their personhood. This embodiment of will justifies the individual having dominium over the property, as it is to be treated as part of his or her empirical self. For another to use the property would be an invasion of bodily integrity, and therefore the entitlement of the individual invoking the personhood claim should be protected by rules prohibiting such trespass. Therefore, the personality theory of property extends the assault analogy by extending its scope to invasions of bodily integrity that may occur once personhood-constituting claims to property are recognised. ${ }^{9}$

\section{Hegelian Model}

The origins of the personality theory of property can be found in the philosophical scholarship of Hegel, most notably in his seminal text, Philosophy of Right. In Hegel's personality theory an individual embodies his personality in property by projecting and externalising his personality into previously unoccupied objects. To embody one's personality in an external object one must use and take possession of the item. ${ }^{10}$ This in turn precludes a second man taking possession of something that is already the property of another, ${ }^{11}$ and the first possessor will be considered the true owner, as there is no property left for another man to take. ${ }^{12}$ Waldron describes the embodiment of will as a two way process: first the object is effected by your will, and second, as a result of that effect, it makes certain uses of that object possible that otherwise would not have been possible. ${ }^{13}$

Once an individual has embodied their will in the external object, that object becomes part of their person, in the same way that their physical form is constitutive of their person; this is the justification for the acquisition of property by an individual. However, Hegel's personality theory does not concentrate solely on the individual, and does recognise a role for the group or community; this role is not equivalent to the role of the individual and their will, but it is crucial to establishing a personhood

\footnotetext{
9 JW Harris, Property and Justice (Oxford University Press 1996) 213-19.

${ }^{10}$ GWF Hegel, Philosophy of Right (T Knox tr, Clarendon Press 1952) 49 para 60.

${ }^{11}$ Ibid 45 para 50.

12 Ibid 49 para 61.

13 J Waldron, The Right to Private Property (Oxford University Press 1988) 349.
} 


\section{THE DENNING LAW JOURNAL}

claim. There are three important references to the community in Hegel's work.

First, Hegel requires the embodiment of a person's will in an external object to be recognisable by others, and the presence of other human beings in the world is essential for that recognition. For a person to have something as his or her property, there must be those in the world who do not have that item as their property, and who can recognise the property claim of someone else. ${ }^{14}$ Unless the individual claiming the object to be theirs is doing so in the context of the group, there is no value or substance to the claim, as the right to the property has no correlative duty.

Second, Hegel incompletely introduces the notion of autonomous groups, and gives particular attention to the family unit and their property relationships. ${ }^{15} \mathrm{He}$ treats the family in the same way as an individual by asserting that the family only has an external existence through property; "and it is only when this property takes the form of capital that it becomes the embodiment of the substantial personality of the family." 16 The desires and needs of particular individuals in the family unit are transformed into the care for common possessions. Hegel explains that whilst each member of the family has no property that he can call his own, he has a right to the common stock.

The idea that family members share in a common stock initially looks appealing to the aim of this article: applying the personality theory of property to the communal claim. If the group or community that is seeking to establish an entitlement to property can be considered as analogous to the family unit, it seems that it is possible to assert that the community has no external existence until they embody their will in property. This embodiment will be possible if each member of the community is willing to give up their individual entitlement in favour of a share in the common stock held by the community unit. However, this initial reading is flawed and unhelpful. Hegel requires that the husband, as the head of the family, must represent the legal entity and that his powers of administration may clash with the right of the individual family members to the common stock. This clash could eventually lead to 'partition' and 'contingency'. ${ }^{17}$

Therefore, Hegel's autonomous family group does not advance the case for the recognition of communal property-holding any further. It seems difficult to understand the family unit as a communal holding mechanism as long as the administration of the property can only be conducted by one of those persons entitled to the common stock. One of the primary problems

\footnotetext{
${ }^{14}$ S Munzer, A Theory of Property (Cambridge University Press 1990) 69.

${ }^{15}$ Hegel (n 10) paras 169-71.

16 Ibid 169.

17 Ibid 171.
} 
with community title is that it is not recognised in law, and even those that are recognised do not have the characteristics of a true communal regime. They invariably rely on the right of one person to administer the property and represent the other members of the community, rather than recognising a collective entitlement to manage and administer the property. This concept of communal-holding bears some resemblance to a trust relationship: the individual with the power of administration holds the common stock on trust and manages it for the benefit of the beneficiaries, who are the members of the family unit. Therefore, it seems that Hegel's conception of the family is little more than a trust-like relationship, and advances the possibility of applying the personality theory of property to communal claims no further. Only if the notion of the autonomous group is further developed will it be possible that the property and personhood claim could be used to substantiate a community entitlement to property.

Finally, Hegel explicitly cautions that individual property rights cannot prevail over demands that may be made for the realisation or maintenance of a genuine ethical community or state. ${ }^{18} \mathrm{He}$ also goes further by saying that the state may cancel property rights in exceptional circumstances. However, he also renders this unusual, as the state has actively sought to promote private property as "no community has so good a right to property as a person has". ${ }^{19}$ Therefore, in this instance, the role and entitlement of the community seems to be subordinate to the property of individuals, unless exceptional circumstances prevail.

\section{Neo-Hegelian Conceptions: Personal and Fungible Property Claims}

Hegel's work has been examined and reformulated in many of the texts that are referenced throughout this article. One of the most notable contributions to this Neo-Hegelian restatement is in the work of Professor Radin, who notes that "[a]lmost any theory of private property can be referred to some notion of personhood" ${ }^{20}$ She frames her inquiry as being an exploration as to how the personhood perspective can help resolve specific disputes between rival claimants. Therefore, Radin's work could be vitally important to the adjudication of disputes between an individual and a community that lay claim to the same resource.

Both Radin and Hegel proceed from the same basic premise: that to achieve proper self-de velopment an individual needs to control resources in the external environment. Yet, despite being a species of the same theory,

\footnotetext{
${ }^{18}$ Waldron (n 13).

${ }^{19}$ Hegel (n 10) additions to para 46.

${ }^{20}$ MJ Radin, 'Property and Personhood' (1982) 34 Stanford Law Review 957.
} 


\section{THE DENNING LAW JOURNAL}

the personhood perspectives put forward by Hegel and Radin differ in a number of ways. The most crucial of these differences is the conception of the 'person' that each is deploying. As far as Hegel's personhood perspective is concerned, a person is not fully constituted and capable of being a person until they have property and control over resources in the external environment. Therefore Hegel's person is akin to the conception of the person that is prevalent in the philosophy of Kant. Hegel's person is an autonomous being that is capable of holding rights, and thus does not have any individuating characteristics until these rights are acquired. On the contrary, Radin adopts a view of the person that does not eliminate their individuating characteristics. Her person is already fully formed and constituted when he projects his personality into the world, and the property relationship allows the individual to express himself in the outside world, rather than attain status as a person.

Using this conception of the person, Radin pursues what she labels as the 'intuitive view' of property and personhood, which is wholly subjective. She argues that most people possess objects that they feel are almost part of themselves because they "constitute ourselves as continuing personal entities in the world". ${ }^{21}$ To measure the strength of the connection between an individual and the objects that they possess Radin suggests the metric to be the level of pain that would be incurred should the individual be deprived of that object. On this measurement, if the pain caused by the loss of the object cannot be alle viated by the replacement of the object, it is likely that the object is bound up with the holder and is closely related to their personhood. The example that Radin provides is that of a wedding ring, to which the wearer would attribute a sentimental value that could not be replicated by a replacement ring or through substitution for monetary value. If, however, the wedding ring were stolen from a jeweller, it is likely that a replacement ring or the monetary value of the ring would be a sufficient remedy to alleviate the pain caused by its loss. Unless there are special circumstances it seems a safe presumption that the ring has no sentimental value to the jeweller, who views the ring as profit. Radin has respectively labelled the claim of the wearer of the ring and the jeweller as personal and fungible property claims. She presents these two claims in the form of a dichotomy, although she does also acknowledge that objects may shift between the categories of personal and fungible property, or they may fall out of the categories of property altogether. ${ }^{22}$

Radin's view is subjective in the sense that the objects that may be bound up with individuals, through the metric of the pain incurred on their loss, will vary greatly from person to person. One individual may view their

${ }^{21}$ Ibid 959.

${ }^{22}$ Ibid 966-67. 
Rolex as a financial investment, which could be replaced by a watch of the same specification and vintage (or its monetary value), whereas others may have an attachment to their Rolex as a gift or family heirloom. Similarly, some individuals may feel a deep attachment to items that others view as absurd or odd, but the pain that would be caused by the loss of these items qualifies them as closely related to the personhood of the individual. It is unclear where the limits of the tolerance for personal-property claims in the subjective view are. There must be a dividing line between those claims that are valid and acceptable, and those that are simply fetishes that are not, or arguably should not, be closely linked to personhood. All personhood claims are based on the preferences of individuals, but there must be objective criteria that differentiate between good and bad identification with external objects. ${ }^{23}$

Once a valid connection to an external object can be substantiated, the personality theory of property suggests that the property claims that are constitutive of personhood have a stronger moral claim than property claims that have an instrumental purpose. In short, personal claims to property should be protected 'against invasion by government and against cancellation by conflicting fungible property claims of other people'. ${ }^{24}$ Personal-property claims should take priority over fungible property claims, even when the fungible property claim is established first in time. This general rule may be rebutted in exceptional circumstances where the property claim can be proven not to be personal, or where is can be deemed not to be so personal as to outweigh the importance of the government taking the object over which the claim is made for a particular social purpose. ${ }^{25}$ If the latter circumstance occurs, it is likely that the level of compensation awarded for the deprivation of the property would reflect the personal nature of the property claim (notwithstanding the fact that the personal claim is unlikely to be adequately compensated through the mode of damages).

At first glance the rule that personal property claims should take priority over fungible claims, even where that fungible claim is established first in time, seems to contradict Hegel's notion that once property has been occupied there is no property left for another man to take. If a property claim can be displaced by a competing property claim it suggests that there was residual property available for occupation, the occupation of which can eventually result in the total displacement of the existing fungible claim. However, on a closer reading, the combined effect of Radin and Hegel seems only to be that the fungible claim should not be protected against a

\footnotetext{
23 Ibid 961.

${ }^{24}$ Ibid 1015.

25 Ibid 1005.
} 


\section{THE DENNING LAW JOURNAL}

subsequent personal claim; only existing personal claims should be protected against subsequent claims (whether personal or fungible), whereas fungible claims will only be protected against subsequent fungible claims. The fungible claim does not give rise to the same entitlement as a personal claim. The personal claim precludes another from claiming an entitlement to the property, as there would be no property left for another man to take once that property is constitutive of the personhood of the first occupant. Conversely, fungible claims can always be displaced where an individual embodies their will in the object and links it to their personhood, regardless of whether the fungible claimant was the first occupant or not. Therefore, the personality theory of property is normative, insofar as it suggests that property constitutive of personhood is worthier of protection than other property claims, and that personal-property claims give rise to a stronger entitlement.

The inquiry in this article has adopted the personal/fungible dichotomy because its purpose is to adjudicate between competing claims to the same resource. In the context of the wedding ring example above, if there were a conflict between the claims of the wearer and the jeweller, the claim of the wearer would take priority, as their claim is a personal one. The ring is bound up with the personhood of the wearer, whereas the jeweller has only an instrumental value for the ring, rendering his claim fungible. The same reasoning applies to natural resources, such as land. For example: if person A builds their home on a plot of land (we will assume for the moment that this is done lawfully), and the interest that person B holds in the land is purely financial (such as being the landowner), and Person B seeks to use the land in a way that is inconsistent with A's home being on the land (sale or development with the intention of making financial gain etc.), the claim of person A should prevail, unless there are exceptional circumstances. Person A has a personal claim over the land; the land is the site of their home to which they have an attachment. It is unlikely that a replacement home will hold the same value for Person A as their present home does. This home has fostered relationships, memories and sentiment that a replacement house would not have. On the contrary, the landowner who holds a purely financial interest is asserting a fungible property claim only as he attributes an instrumental value to the land. Furthermore, Person B would, in this scenario, also be satisfied with replacement land or monetary compensation on the loss of the land. In a direct clash between the two, the personal claim has the greater moral value, and should be protected. Person $B$ should be prevented in engaging in the use that is inconsistent with the claim of person A.

The personhood perspective does not exist only in the hypothetical instance, nor does it only exist at a theoretical level. There are many legal doctrines that, whilst they are not labelled as such, either expressly or 


\section{COMMUNITY PROPERTY CLAIMS}

implicitly acknowledge the personal-property claim as worthy of protection over those claims that are fungible. For example, allowing individuals to acquire rights over land by prescription, and allowing the acquisition of title by virtue of long use through adverse possession, both acknowledge that those who use the land for a sustained period bind themselves with the land in such a way that gives rise to a property claim. This property claim often takes the form of a personal-property claim, ${ }^{26}$ and in the case of adverse possession may even lead to the fungible claimant losing title to the land altogether. Another example can be found in the overriding interest of persons in actual occupation. ${ }^{27}$ The overriding interest protects unregistered interests in the land, provided those rights are coupled with occupation of the land, even in the presence of a conflicting claim. If the individual occupies the land it is assumed that their personhood is closely linked to the land in such a way that the loss of the land cannot be adequately compensated through substitution of the land, or provision of monetary compensation. They have an entitlement that should be upheld against fungible claims of purchasers, or a pre-existing personal claim that should take priority over new personal claims that may arise.

\section{Personhood in the Group Context}

The contentious element of this project is extending the normative principle of favouring personal claims to a conflict concerning the claim of a group or community against claim made by a private landowner. The personal/fungible dichotomy has rarely, if ever, been analysed outside the context of a conflict between two individuals. It is essentially a way of justifying a private property claim and allocating a resource or object to one person over another. However, it does not seem beyond the realm of logical application that, if a group could establish a personal-property claim, it should defeat the fungible claim of others. The application of the dichotomy and normative principle to this effect would be radical; the group would attain new competencies and status, and is not without its difficulties, but it is certainly not impossible.

Some headway has already been made in applying the personhood perspective to community claims. For example, Professor Harris suggests that the assault analogy actually has more force when discussing the concept in the context of community claims to first occupancy. He suggests that to take artefacts that are closely identified with the cultural identity of

\footnotetext{
${ }^{26}$ A Clarke, 'Use, Time and Entitlement' (2004) 57 (1) Current Legal Problems 239.

${ }^{27}$ Land Registration Act 2002, sch 3 para 2.
} 


\section{THE DENNING LAW JOURNAL}

a particular community constitutes a natural wrong. ${ }^{28}$ Furthermore, he suggests that that analogy is even stronger in the case of land if the community is in occupation of the land and relies on its use for economic survival, as incompatible uses by newcomers will constitute an attack upon the community's collective integrity. ${ }^{29}$ Whilst Harris is not directly addressing a group personal-property claim, the personality theory relies heavily upon, and indeed extends, the assault analogy that he is discussing. Furthermore, there are similarities between the first occupancy rule and the personality theory of property that enhance the relevance of Harris's observations in the context of the personality theory of property. The key similarity is that once property has been occupied by force of individual will, and that claim is personal, there is no property left for another man to take. In much the same way, once property has been taken or occupied for the first time, the individual engaged in that act of taking has the best title to the object.

Radin does not herself take the additional step of applying the personal/fungible dichotomy in the group context. However, similarly to Hegel, Radin does indicate that the group has some role in the personality theory of property. She briefly revisits Hegel's assertion that an individual can only find self-determination in the context of a group, and notes that this may have political consequences for group claims on certain resources in the external world. ${ }^{30}$ It seems that, for Radin at least, applying the personhood perspective to a group claim to protect that group's entitlement is not beyond possibility, although that step is still only in elementary form. In the context of eminent domain (compulsory purchase), Radin suggests that:

\section{Although the personhood perspective has not yet yielded a general limitation on eminent domain, some fragmentary evidence suggests that group property rights, if connected with group autonomy or association, are given enhanced protection. ${ }^{31}$}

This project seeks to achieve what the neo-Hegelians have yet to do: to apply the personal/fungible dichotomy to claims made by groups and communities to natural resources, such as land, and to allow those groups that succeed in establishing a personal-property claim to defeat any competing fungible claims. The application of the theory in this way will potentially allow those communities that use land to defeat the claims of

\footnotetext{
${ }^{28}$ Harris (n 9) 216.

29 Ibid.

${ }^{30}$ Radin (n 20).

${ }^{31}$ Ibid 1006.
} 
those who seek to use the same land in a way that is inconsistent with the use of the community. For example, recognising the personal-property claim of a community that use land for the purposes of recreation could protect these recreational spaces from inconsistent use that is motivated by financial purposes, such as development or enclosure. There is currently very little legal recognition of community rights to resources, and those mechanisms that do exist are tempered by political policy objectives. By grounding the community entitlement in a strong theoretical framework, such as property and personhood, the chances of achieving legal recognition of community claims and entitlement are greatly increased.

In principle, the application of the personality theory of property to community claims seems plausible. However, there are a number of difficulties that must be explored. The primary difficulty is the nature and conception of the group. At present a group or community does not enjoy the same legal and moral status as an individual to whom the theory is applied. Groups are inherently different in that they are a collection of wills, rather than one single will that is seeking to be embodied in the external world; and it is to this problem that the attention of this article will now turn.

\section{DEFINING THE COMMUNITY}

In the attempt to apply the personality theory of property to communal claims the initial challenge is to reconceive the role of the group. It is clear from the preceding discussion that the group dynamic has some, albeit limited, role in the personality theory of property. The settled role of the group, which is in effect the society in which the private property-owning actors operate, is to act as an audience to the claim of the private individual. ${ }^{32}$

The present function of the group can therefore be understood by using a centuries-old puzzle; if a tree falls in the woods and there is nobody around to hear it fall, would it make a sound? If a private individual established and then communicated a private property claim over a natural resource, and there was nobody around to receive that communication, would the claim still exist? The group in the property claim serves the same function as the ear with the falling tree. The falling tree causes a number of vibrations in the air, or sound waves. However, 'sound' is something within human experience, until the vibrations reach a human ear and are synthesised, they will only ever be vibrations. The same reasoning applies to the property claim: until that claim is communicated to, and understood

\footnotetext{
${ }^{32}$ See also Rose (n 6) chapter one, where the importance of the audience and the symbols of possession are discussed.
} 


\section{THE DENNING LAW JOURNAL}

by, the society in which the claimant lives, it has no substance or meaning. By receiving the communication and understanding the property claims made by others the claim is realised, and the entitlement can be respected and observed by the members of society.

The group or society is, on this conception, little more than a collection of self-interested individuals; there is nothing inherently cohesive or grouplike about them. The group does not have a level of collective autonomy that elevates it to the status of a right-holder, and which allows the personality theory of property to substantiate a property entitlement in their favour. The individual members and their property claims exist solely as a comparator for the claims of others; ${ }^{33}$ they allow for the distinction between that which is 'mine' and 'thine', a distinction that, when made and understood, gives the private entitlement of one individual real substance.

The closest that this disparate conception of the group gets to being communal is when a number of individuals with similar interests associate with one another. However, there is a marked difference between groups in which each individual holds a right individually and severally, and a group in which the group itself has a right. A group, whose members make the same property claim, or hold the same property rights, does not automatically lead to a group that itself holds a right. For example, every member of a community may hold the benefit of an easement, which they exercise in common with other members of the community who also have the benefit of an easement that is substantially similar to their own. This state of affairs does not mean that the community itself has an easement, but rather that the community is comprised of a number of similarly situated individuals. Professor McDonald labels this collection of individuals a 'class action concept of collective rights', and he defines the group as a "convenient device for advancing the multiple discrete and severable interests of similarly interested individuals." 34

This article seeks to go further than the class action concept of collective rights, and seeks to justify the group itself making a property claim and holding the consequential property rights. The role of the group should be more substantial than just a mechanism advancing the similar interests of individuals. As McDonald himself argues:

\footnotetext{
${ }^{33}$ It is observed that there must be poverty for there to be private property, however the link between those who are propertyless and their ethical status and incomplete personhood is unclear, see Waldron (n 13) 377-89.

34 M McDonald, 'Should Communities Have Rights? Reflections on Liberal Individualism' (1991) 4 Canadian Journal of Law and Jurisprudence 217-18.
} 


\section{COMMUNITY PROPERTY CLAIMS}

...class action rights are too thin a model for collective rights. A major aim of group rights is to protect interests which are not thus severable into individual interests for the rights in question benefit the group itself by providing a collective benefit. ${ }^{35}$

\section{Group Personhood}

The conception of the group must be modified for the personality theory of property to allow groups themselves to establish personal-property claims, something that Hegel did not do, and that the neo-Hegelian scholars have yet fully to do. In order to use the personality theory to justify the recognition of communal property rights the group, as a collective, must itself be able to make a claim and must be ascribed the same competencies and power of the private individual.

However, the difficulty with considering the group in the same light as an individual is that they are inherently different. The personality theory of property embodies the will of an individual in an external inanimate object. This process is easy to rationalise when it is applied to a private individual who has a single identifiable will. Yet, when applied to the group dimension, a problem emerges. The group contains a number of individuals, each with their own will. It is likely, if not inevitable, that these individual wills will in some way be inconsistent with one another. Therefore, the first task is to organise disparate individuals into a united group.

In the context of arguing that Hegel provides a rights-based, as opposed to utilitarian, argument for private property, Professor Waldron suggests that Hegel himself addresses this concern. Waldron states:

\section{...Hegel did not believe that there was ultimately any distinction between the collective interests of a community and the individual interests of the members of that community. That the goals of the community to which he belongs should be pursued and realised- that is the ultimate interest of each individual. ${ }^{36}$}

This interpretation does not leave room for inconsistencies or incompatibility in the wills of the individual members of the community. By virtue of belonging to the community every member has the common will of pursuing the interests of the community. However, Waldron's statement presupposes that the community has an identified goal that it

\footnotetext{
${ }^{35}$ Ibid.

${ }^{36}$ Waldron (n 13) 347.
} 


\section{THE DENNING LAW JOURNAL}

seeks to pursue, which in turn transposes itself into the will of the individuals belonging to the community.

Therefore, it seems that Waldron is missing a step, as the group must first determine the goals and interests that it wishes to pursue before this can be adopted as the interest of the collective. For the community to determine the goals that it wishes to pursue there must be some decisionmaking process, of which the members of the community consider the outcome binding. There must also be some form of governance within the community and the ability to police those members of the community who diverge from the determined aims. Therefore, a community that is able to achieve a united will, and group personhood that can project into the external world to establish property claims, must possess characteristics that are different from those groups (or society in general) that merely facilitate the private property claims of individuals. McDonald supports this assertion and argues that

For a group to function as a rights-holder its members must see themselves as normatively bound to each other such that each does not act simply for herself or himself but each pays her or his part in effectuating the shared normative understanding. ${ }^{37}$

\section{Mutual Self-Interest Commons}

In order to deduce the group characteristics that are necessary to facilitate the adoption of one collective aim, it is necessary to identify the type of common that this two-part article seeks to justify. There are three types of common-property regimes: no property, open access and limited access. The generic terms 'common-property' and 'communal property' are unhelpfully used to refer to all three. Professor Bromley suggests that this interchangeable use of language to describe different circumstances and legal relations leaves the progress of understanding these concepts impeded. ${ }^{38}$ Ironically, even Bromley himself conflates the no property regime with open access property, stating that an open access regime refers to resources of which there are no property rights, or a resource that is res nullius. ${ }^{39}$

The definitions that this paper adopts are as follows. A no property regime is one where everyone in the world has the freedom, but not a right,

${ }^{37}$ McDonald (n 34); see also AM Honoré, 'Groups, Laws and Obedience' in AWB Simpson (ed), Oxford Essays in Jurisprudence (Oxford University Press 1973) 2. ${ }^{38}$ DW Bromley (ed), Making the Commons Work: Theory, Practice and Reality (Institute for Contemporary Studies 1992) 3.

${ }^{39}$ Ibid 4. 


\section{COMMUNITY PROPERTY CLAIMS}

to use the resource. This equates to a Hohfeldian privilege and the correlative no-right not to be excluded from the use. In contrast, an open access property regime is one where every person has a Hohfeldian right to use the resource, and all others have a duty not to exclude those who enjoy these rights; the paradigm case of which would be a right of way. A limited access regime also hinges on the right-duty correlate, but only those persons who are members of a particular community have the right to use the resource. It has been argued that the limited access common is the only species of common that has any chance of prosperity and of rebutting the tragedy of the commons, as the limited community of users is likely to have the necessary regulation in place. ${ }^{40}$

The group personhood claim seeks to establish a limited access common, also referred to as a mutual self-interest common (these terms can be used interchangeably). By establishing a group personhood and projecting the community personality into the external world, natural resources (and specifically land) are subject to the use rights and entitlements of the community, who may exclude all those who fall outside of the community.

Professor Rose equates the open access regime with the use rights of the 'unorganised public', whereas a limited access common used by a smaller group or community has a greater resemblance to private ownership. ${ }^{41}$ The cornerstone of a private property regime is that that titleholder must be able to exclude all others from their property. Similarly, the community has the right to exclude anyone who is not a member from the use of the resource. Indeed it is likely, if not almost certain, that this right to exclude is what allows mutual self-interest commons to survive, as will be discussed shortly. If this assertion by Rose is in fact true, then it seems that a limited access common may not be a true 'common-property' regime at all, but rather a sub-species of private property that recognises the legal entitlement of more than four persons. ${ }^{42}$

However, whilst the small user group of a limited access common may well resemble private ownership, there is a key distinguishing factor; the alienability of communal property is markedly different to that of privately owned property.

The rights of the user in both common-property (used in this sense to mean limited access commons) and open access regimes have been

\footnotetext{
${ }^{40}$ Clarke (n 7) 323.

${ }^{41}$ Rose (n 6) 117.

${ }^{42}$ English law permits the legal title of property to be held by four persons or fewer, as stipulated by the Law of Property Act 1925, s 34(2), and the rights of any further parties will be recognised in equity only.
} 


\section{THE DENNING LAW JOURNAL}

extensively examined. In particular, Professor Eggertsson has highlighted the differences between the rights of the user in open access commons, and those in pure common-property regimes. ${ }^{43}$ By adopting the spectrum of user rights put forward by Professors Ostrom and Schlager, Eggertsson compares the differences in entitlements between the two regimes. The possible entitlements that exist are: ${ }^{44}$

1. Authorised access to enjoy non-subtractive benefits

2. Right to withdraw resource units

3. Right to manage and improve the asset

4. Right to exclude others from entering and withdrawing resources

5. Right to sell or lease the asset

Eggertsson suggests that open access regimes will entitle users to the first two incidents, whereas common-property regimes will entitle users to the first four. ${ }^{45}$ Crucially, even a common-property regime will not entitle its users to the fifth incidence, as this is what separates common-property regimes from all other arrangements that include exclusive rights. True common-property is inalienable.

Eggertsson argues that a joint ownership arrangement that includes the power of alienation cannot be a common-property arrangement on the definitions given by Ostrom and Schlager. ${ }^{46}$ Therefore, some of the limited mechanisms that are recognised for the joint holding of property, such as the company, should not be defined as a common-property arrangement. This view is supported by others; for example, Professor Clarke describes the corporate form as "inappropriate- although not necessarily unworkablefor communal resource holding". ${ }^{47}$ Furthermore, the aforementioned distinction between group rights and the class action concept of collective rights would, in this context, suggest that the property rights in the common-property arrangement should benefit the community as a whole, not the individual members of the community. The rights that exist within a true common-property arrangement cannot be severed into individual interests that can be alienated; the property entitlement exists only as a

43 T Eggertsson, 'Open Access Versus Common Property' in TL Anderson, FS McChesney (eds), Property Rights: Cooperation, Conflict and Law (Princeton University Press 2003).

44 Ibid 74; see Edella Schlager and E Ostrom, 'Property-Rights Regimes and Natural Resources: A Conceptual Analysis’ (1992) 68 (3) Land Economics 249.

${ }^{45}$ Eggertsson (n 43) 74.

46 Ibid.

${ }^{47}$ Clarke (n 7) 350. 


\section{COMMUNITY PROPERTY CLAIMS}

whole, and belongs to the group, not to each and every member of the group as an individual.

One way to explain the inalienability of common-property is to view the property arrangement as comparable to a trust arrangement, such as the public trust doctrine. However, whilst in the public trust doctrine it is the state that holds the property on trust for the use of the general public, in a common-property regime the community hold the property on trust for the benefit of the present and future members of the community. This intergenerational equality of benefit prevents the community from alienating the property at the expense of the use of future generations, and is the factor that distinguishes the limited access common from private ownership. Private property arrangements predominantly focus on the freedom of the present right holder. Unless that right holder voluntarily undertakes to preserve their property for future generations and their heirs, there is no legal obligation to preserve the capital of their property in such a way. This theory also seems to attract some implicit approval from Ostrom, who suggests that a successful community that establishes a limited access common will have an "intricate web of connections among participants who share a past and expect to share a future."48

Another way to explain the inalienability of common-property falls squarely within the application of the personality theory of property to communal claims. As Professor Harris notes:

\section{...[a] successful invocation of the personhood-constituting argument would not yield full-blooded ownership. In particular, it appears incompatible with freedom to transmit. ${ }^{49}$}

The conceptual consequence of allowing transmission of property rights that have been established through a personal-property claim is to transfer a portion of the claimant's personhood, which is in fact nontransferrable. ${ }^{50}$ Professor Benson supports this contention in his analysis of Hegel's philosophy, where he argues that only things can be alienated, and as personality is not a thing, it cannot be alienated. Looking specifically towards paragraph 66 of Philosophy of Right, Benson says that "whatever constitutes a person's self-relatedness... whatever belongs to a person's inward, thinking relation to him or to herself, must be treated as

\footnotetext{
48 A Margalit, 'Commons and Legality' in G Alexander, E Penlaver (eds), Property and Community (Oxford University Press 2010) 145.

${ }^{49}$ Harris (n 9) 221.

${ }^{50}$ PF Strawson, Individuals (Methuen \& Co Ltd 1959) 97-98.
} 


\section{THE DENNING LAW JOURNAL}

inalienable". ${ }^{51}$ Therefore it seems wholly inconsistent to allow objects or resources, regardless of whether they are subject to a communal or individual personal-property claim, to be alienable. Only objects or resources that are subject to a fungible property claim should be transferrable in this way, and personal-property claims would need to become fungible property claims before any alienation of the subject of the claim could occur.

\section{Required Community Characteristics}

For a community successfully to establish a mutual self-interest common it must exhibit a number of characteristics. These characteristics allow the community to lay claim to the resource, and will also be instrumental in facilitating a group personhood claim.

A significant and helpful contribution to the scholarship in this area can be found in the work of Professor Clarke who, after a survey of the literature (particular that of Professor Ostrom), suggests six important community characteristics: exclusion of non-members, mutual self-interest, homogeneity of interest, cohesive community, idiosyncratic regulation and the availability of sanctions. ${ }^{52}$

\section{(i) Exclusion of non-members}

The right to exclude others from the use of property that we consider to be ours is an important, if not the most important, characteristic of private property. ${ }^{53}$ It is also the hallmark of property rights stated in Blackstone's classical view of property. A successful limited access common also relies on the ability of the community to exclude non-members of the community from using the resource.

Clarke, by making reference to Ostrom, summarises that:

The tragedy of the commons is averted by communal holding only if the resource is controlled by a group which is small and cohesive enough to permit members, at a sufficiently low cost, to communicate between themselves and devise and enforce rules regulating their own use of the resource. But group control depends

\footnotetext{
${ }^{51}$ P Benson, 'The Priority of Abstract Right, Constructivism, and the Possibility of Collective Rights in Hegel's Philosophy' (1991) 4 Canadian Journal of Law and Jurisprudence 257, 283.

52 Clarke (n 7).

${ }^{53}$ Rose (n 6) see chapter one generally.
} 


\section{COMMUNITY PROPERTY CLAIMS}

on being able to keep out non-members, or, what amounts to the same thing, on all resource users being subject to the social norms of the group regulating use..$^{54}$

\section{(ii) Mutual self-interest}

As alluded to during the previous discussion, there is the common misconception that communal property must be available to all. However, Clarke contends that a successful communal resource holding must be "just as private to the community as private property is to the private property owner." 55 The common is governed by a mutual self-interest, not the greater public interest, and its survival is probably contingent on this.

\section{(iii)Homogeneity of interest}

The requirement for the homogeneity of interest runs to the core of Waldron's assertions about the community dynamic. If many different, and sometimes incompatible, interests exist within the community it will be difficult to reach an agreement on the collective goal to be pursued. Studies have shown that disparate communities are not bound to fail, ${ }^{56}$ but the likelihood of them doing so is far greater if homogeneity of interest cannot be achieved.

\section{(iv) Cohesive community}

Clarke suggests that the need for a cohesive community has a greater significance than the need for homogeneity of interest, as the cohesive community provides both the means and the method for promoting the mutual self-interest. ${ }^{57}$ If the community are unable to act in a united fashion, and interact in a way that includes all members of the community, it will be unlikely that a homogeneous interest will be formulated and pursued.

The importance of a cohesive community appears to have been acknowledged in English law in the instances where the community interest

\footnotetext{
${ }^{54}$ Clarke (n 7) 328.

55 Ibid 329.

${ }^{56}$ E Ostrom, 'The Rudiments of a Theory of the Origins, Survival and Performance of Common-Property Institutions' in DW Bromley (ed), Making the Commons Work: Theory, Practice and Reality (San Francisco: Institute for Contemporary Studies 1992) 293.

${ }^{57}$ Clarke (n 7) 329-30.
} 


\section{THE DENNING LAW JOURNAL}

and entitlement to use land is recognised. For example, land may be designated as a town or village green if it can be shown that a significant number of the inhabitants of a locality or neighbourhood within a locality have used the land as of right for a period of twenty years. ${ }^{58}$ Whilst 'locality' has a technical legal meaning, ${ }^{59}$ Sullivan $\mathbf{J}$ has suggested that a neighbourhood must have a 'sufficient degree of cohesiveness'. ${ }^{60}$ The example of the town and village green as a mechanism for acknowledging communal rights over land will be examined in the second instalment of this two-article series.

\section{(v) Idiosyncratic regulation}

Communities that successfully establish mutual self-interest commons also develop a variety of regulations that meet the needs of their community. The precise rules that are developed will be unique to that particular community and may regulate who can use the resource, when they may use it and how. Crucially, these rules will be developed by the community itself and will be informed by the shared experience of its members; this is an important point to note, as the law does not create groups and they are not legal fictions. It is not objective factors, such as race, culture or language that makes a collection of individuals into a community or group, but rather subjective factors and a shared understanding. ${ }^{61}$ Objective factors may be a good indication that the necessary shared understanding exists between the members of the group and that idiosyncratic regulation will develop, but this is neither a necessary nor sufficient condition. Only those with the subjective knowledge of the community will be able to initiate successful regulation of the group, and the subjective knowledge of the group does not necessarily flow from objective assessment.

An example of idiosyncratic regulation that Ostrom provides is the Alanya inshore fishery. ${ }^{62}$ Following a number of experiments in the allocation of fishing sites, the local cooperative devised a number of rules for the efficient and fair allocation of fishing sites among all licensed fishers

\footnotetext{
58 Commons Act 2006, s 15.

59 'Locality' is defined as an administrative district or area with legally significant boundaries in Paddico (267) Ltd v Kirklees Metropolitan Council [2011] EWHC (Ch) 1606 [97] (Vos J).

${ }^{60} R$ (Cheltenham Builders Ltd) v South Gloucestershire District Council [2003] EWHC (Admin) 2803 [85] (Sullivan J).

${ }^{61}$ McDonald (n 34) 218, 219.

62 Ostrom (n 2) 17-20.
} 


\section{COMMUNITY PROPERTY CLAIMS}

in Alanya. These rules included provisions that rotated fishers between fishing grounds, so that each had an equal chance of fishing the most prosperous sites. Ostrom notes that not only did these rules develop from within the group rather than being imposed from outside the group, it would have been impossible for an outside agency such as the state to achieve the same efficiency in the rules. ${ }^{63}$ Devising these rules required knowledge that could only be gained by fishing in the area for an extended period. The task of mapping the local fishing sites, the migration of the fish and the effect that fishing had on the migration could only be done by those with local knowledge and vast amounts of experience.

Furthermore, Bromley also suggests that influences and rules that originate from outside the group may actually destroy the resource and the common-property regime. ${ }^{64}$ In a similar example using fisheries, he suggests that governments often seek to modernise fishing practices by subsiding new technologies. The increase in fishing capability upsets institutional arrangements and leads to overfishing, yet many blame the common-property regime and not the introduction of alien fishing methods and technology. On the contrary, Bromley suggests that those outside the community will hail the introduction of the technology as a success, branding the institutional arrangements 'primitive or quaint' ${ }^{65}$

It is possible that the internal idiosyncratic regulation does not even arise from a conscious, or democratic, decision-making process. The most prevalent way in which commons have historically come into being is through custom. The use of the resource may be governed by centuries-old understanding of entitlements between a community of users.

\section{(vi) Sanctions}

The requirement that the group has sanctions has two limbs. First, Ostrom notes that successful communities will adopt a system of mutual enforcement. For example, in the Alanya fishery the fishers themselves monitor the use of the agreed fishing locations, and the enforcement of the rules allocating their use. Cheating the rotation system and using a more prosperous site that one is not entitled to on a particular day would not go undetected by those who are entitled to use those sites; the fisher who is burdened by the cheat will take measures to protect his entitlement. The other fishers, who will be seeking to disincentive cheating so that their entitlement to fish on the prosperous sites is not interfered with, will support

\footnotetext{
${ }^{63}$ Ibid 20.

${ }^{64}$ Bromley (ed) (n 38) 8.

${ }^{65}$ Ibid.
} 


\section{THE DENNING LAW JOURNAL}

him in the hope that there would be a reciprocity of support should they have need for it. ${ }^{66}$

The second limb is that the ultimate sanction for non-compliance with the regulations is exclusion from the resource or from the community that uses the resource. The community polices itself, and those who are identified through the monitoring process as not willing to comply with the rules are expelled from the community.

\section{CONCLUSION}

This two-part article is concerned with justifying the recognition of the rights of a defined community to a natural resource, also known as a limited access common, and not a claim made the by public generally, which is an open access regimes. Despite the key feature of the limited access common being the exclusion from the resource of those individuals who fall outside of the community, there is a marked difference between the limited access common and the private property regime that it resembles: a true commonproperty resource cannot be alienated at the expense of the future generation of users.

In order to justify the limited access common, in the hope of protecting community use claims against claims of private individuals, the personality theory of property can be applied. For a community to have the requisite personality that can be projected into the external world, and establish a claim over natural resources, it must have a number of characteristics. The six descriptive characteristics provided above are by no means an exhaustive list of the characteristics that a community must possess in order successfully to initiate a common-property regime, and neither are they a prediction of the success of a common-property regime. ${ }^{67}$ Indeed, the dominant message of Ostrom's scholarship on this topic is one urging caution against believing that there is one analysis that fits all common property regimes. ${ }^{68}$

However, the listed characteristics are a way of attaining the state of affairs that Waldron; they ensure that the interests of individuals in the mutual self-interest group will be no different from the collective interests

\footnotetext{
${ }^{66}$ Ostrom (n 2) 20.

${ }^{67}$ Clarke (n 7) 329-31.

68 See for example E Ostrom, 'A Diagnostic Approach for Going Beyond Panaceas' (2007) 104 (39) Proceedings of the National Academy of Sciences 15181; E Ostrom, Robust Property Rights Institutions to Manage Local and Global Commons (Presentation to the World Bank - April 26, 2010) <http:// siteresources.worldbank.org/EXTARD/Resources/336681-1236436879081/ 5893311-1271205116054/ostrom.pdf> accessed 25 May 2016.
} 


\section{COMMUNITY PROPERTY CLAIMS}

of the community, which is that the goals of the community should be pursued. The group characteristics listed above promote the required unity, and it becomes possible that the community possesses only one collective will. It follows that there is no reason why this will, like the will of an individual, cannot be projected into the external world.

The second instalment of this article will proceed to apply the personality theory of property to the limited number of community claims that are recognised in English law. The aim of the inquiry will be to establish whether community property claims are afforded the same protection as their private property counterparts that are usually justified by using the personhood perspective. 